\title{
Limpieza de los materiales pétreos de la Catedral de Valladolid \\ (España)
}

\author{
Cleaning of stone materials in the Cathedral de Valladolid \\ (Spain)
}

R. FORT,M.C.LÓPEZDE AZCONA, F.MINGARRO

Instituto de Geología Económica (CSIC-UCMF)

Fecha de recepción: 24-IV-99

Fecha de aceptación: 4-VIII-99

ESPAÑA

\section{RESUMEN}

En las fachadas del conjunto catedralicio de Valladolid se han diferenciado dos tipos de costras negras, una de composición yesifera y otra de naturaleza calcitica. Atendiendo a los parámetros petrofisicos (compacidad, cinemática de sorción y desorción) de las diferentes facies carbonáticas con las que se construyó la catedral, se determina que el método idóneo para llevar a cabo la limpieza de sus sillares es con agua. La mayor efectividad se alcanza con una temperatura del agua de $90^{\circ} \mathrm{C}$ y una presión de 120 bares, a excepción de las pelmicritas detríticas, que dada su baja compacidad la presión no puede ser superior a los 50 bares. Para la eliminación de las costras negras es necesario aplicar previamente un tratamiento alcalino a base de hidróxido sódico y EDTA.

Palabras clave: técnicas de limpieza, calizas, petrofisica, parámetros cromáticos, conservación de monumentos, patrimonio arquitectónico.

\section{SUMMARY}

Two types of black crusts showing gypsiferous and calcareous compositions are recognized on the front-walls of the Valladolid Cathedral. On the basis of several petrophysical parameters, in particular compacity, sorption and desorption kinematics of carbonate rocks used building the cathedral, we conclude that the most appropriate cleaning method of the ashlars is washing with water. Highest efficiency of the method is attained with water at $90{ }^{\circ} \mathrm{C}$ and at a pressure of 120 bars. This assessment is valid for most of the carbonate rocks of the cathedral except for detrital pelmicrites because of their low compacity which makes that water pressure for cleaning must not excced 50 bars. The processing of cleaning with water should be preceded by alkaline treatment ( $\mathrm{NaOH}$ and EDTA) of the rock surface.

Key-words: cleaning methods, limestones petrophysics, chromatic parameters, monuments conservation, architectural heritage.

\section{INTRODUCCIÓN}

Las fachadas de los edificios y monumentos sufren un deterioro importante por acción de la contaminación ambiental de su entorno. Una de las patologías más características es la presencia de costras negras y enmugrecimientos que disminuyen el valor artístico de dichas fachadas.

\section{INTRODUCTION}

Building and monument façades undergo significant decay as a result of the action of environmental pollution in their surroundings. One of the most common pathologies is the presence of black crusts and soiled areas that have a negative impact on the artistic value of these façades. 
Las fachadas de la Catedral de Valladolid tienen un grado de enmugrecimiento elevado, con contrastes cromáticos producidos por la presencia de zonas lavadas por la lluvia y otras con formación de costras negras, dando un aspecto deplorable de todo el conjunto. Esto provoca la necesidad, a la hora de proceder a la conservación de este monumento, de llevar a cabo trabajos de limpieza.

El conjunto catedralicio vallisoletano está constituido por diferentes construcciones que se han ido agregando en sus distintas etapas de construcción. La parte más antigua la constituye la torre-pórtico de la colegiata románica construida en 1095, siendo el resto de la colegiata destruida en 1219. Sobre ésta se construye, en 1228 , la segunda colegiata ya de estilo gótico, siendo ampliada con distintas capillas entre 1319 y 1333. En 1594 se inicia la construcción de la Catedral Nueva con planos de Juan de Herrera, y finaliza en 1729 con Churriguera. Desde su construcción no se ha realizado una intervención de limpieza integral de sus paramentos.

Antes de proceder a cualquier método de limpieza, es necesario conocer, por un lado, las características petrológicas del soporte sobre el que hay que actuar y, por otro, conocer la naturaleza del ensuciamiento. $\mathrm{La}$ técnica de limpieza más idónea es determinada por su efectividad e inocuidad sobre la piedra y pátina de envejecimiento, así como por la sencillez de su aplicación.

\section{MATERIAL Y MÉTODO}

En el conjunto catedralicio se han diferenciado 9 tipos petrológicos (1). En la colegiata existen tres tipos principales. La portada está construida con pelmicritas detríticas (Facies A). El lateral derecho de entrada a la colegiata está realizado con otro tipo de caliza más compacta, que se clasifica como micrita fosilífera (Facies B) y el lateral izquierdo está construido con sillares de pelmicritas fosilíferas (Facies C). En la Catedral Nueva se diferencian dos tipos característicos, el más abundante corresponde a biomicritas (Facies $\mathrm{E}$ ), con rellenos cársticos y abundantes restos de gasterópodos, ostrácodos y oogonios de caráceas. La otra variedad es también una caliza que petrográficamente puede ser clasificada como microesparita (Facies D). En la torre existen varios tipos de piedras, la parte inferior son biomicritas, similares a las existentes en la fachada principal de la Catedral Nueva, y en cuerpos superiores son biomicritas y biomicritas con ostrácodos.

Para poder establecer el método de limpieza más idóneo es necesario conocer la composición y propiedades petrofísicas del soporte, así como la
The façades of the Cathedral of Valladolid (Valladolid, Spain) have a high degree of soiling, with chromatic contrasts caused by the presence of sections washed by rainwater alongside other sections overlaid with black crusts, which gives the monument on the whole a deplorable appearance. Cleaning work is therefore an essential step in the preservation treatment of this monument.

The cathedral is composed of several constructions added on during different periods. The oldest section is the portico-tower that belonged to the romanesque collegiate church, built in 1095. The rest of the building was destroyed in 1219. A new, Gothic collegiate church was built in 1228 on the site of the original building. Further chapels were added between 1319 and 1333. In 1594 work towards the construction of the New Cathedral following plans by Juan de Herrera started. It was finished in 1729 with the architect Churriguera. Since it was built, the cathedral walls have not undergone a complete cleaning treatment.

Before applying any cleaning method it is necessary to be aware both of the petrological characteristics of the material and of the nature of its soiling. The criteria used to ascertain the most appropriate cleaning technique are: effectiveness, innocuousness for the stone and for the natural ageing, patina and easy application.

\section{MATERIAL AND METHOD}

Nine different petrological types have been identified within the cathedral constructions (1). Three main varieties can be identified in the collegiate. The façade is built with detritic pelmicrite (Facies $A$ ). The right side entrance to the collegiate is built with a different, more compact, variety of limestone classified as fossiliferous micrite (Facies B) and the left side entrance with fossiliferous pelmicrite (Facies $C$ ). Two varieties are identified as characteristic of the Catedral Nueva, the highest proportion belongs to the biomicrite variety (Facies E), with karstic fillings and rich in gastropod, ostracod and characeas oogonia traces. The other belongs to a different limestone variety and can be petrographically identified as microsparite (Facies D). Different varieties are found in the tower; the lower body is composed of biomicrites, of similar characteristics to those in the main façade, and the upper bodies are composed of both biomicrites and biomicrites with ostracods.

In order to ascertain the most appropriate cleaning method, knowledge of the composition and petrophysical properties of the material as well as of 
naturaleza del enmugrecimiento. Se realizó un muestreo por extracción de testigos de los materiales representativos de la Catedral, determinándose sus propiedades petrofísicas, siguiendo las recomendaciones de la RILEM (2). El color de los materiales se definió por medio de un espectrocolorímetro (Minolta CM-2002) (3). La escala cromática ha sido la Cielab (4), con unas condiciones de iluminante estandarizado $\left(\mathrm{D}_{65}\right)$, y ángulo de observación de $10^{\circ}(5)$. Los índices de amarillo y de blancura fueron determinados siguiendo las normas ASTM (6). La metodología utilizada ha sido específicamente para calizas (7).

Para medir el grado de enmugrecimiento se seleccionaron 39 sillares, sobre los que se midieron las coordenadas cromáticas. En la colegiata se eligieron 15 sillares, pertenecientes a la Facies C, 7 sillares de la Facies B y 5 sillares de la Facies A. En la fachada principal de la Catedral Nueva, se seleccionaron 12 sillares de la Facies E (biomicrita), por ser el más abundante dentro de la fachada analizada. Sobre cada uno de estos sillares se realizaron 10 medidas cromáticas, distribuidas sobre toda su superficie. Cada medida fue media de tres realizadas en la misma posición, para obtener un valor representativo del conjunto. El número de medidas cromáticas del enmugrecimiento fue de 1,170 .

El análisis de la costra se realizó por medio de microscopía electrónica de barrido con EDAX (MEBEDAX). El análisis químico se realizó por la técnica de ICP-Emisión e ICP-MS.

\section{CARACTERÍSTICAS PETROFÍSICAS}

Los parámetros cromáticos originales de estos materiales están resumidos en la Tabla I. Todos los materiales se caracterizan por una luminosidad alta de sus tonos, con índices entre 70 y 80 unidades, siendo las facies de los paramentos laterales de entrada a la colegiata los que presentan valores ligeramente más bajos. Los sillares tienen un componente de tonalidad amarilla, definido por el parámetro $+b^{*}$, que es más alto para las Facies A y F, siendo estás las que tiene un Indice de amarillo (IA) más elevado, con valores próximos a 17. El indice de blancura (IB) es similar para todos los tipos de materiales, siendo más alto en la Facies D.

En la Tabla II se muestran los parámetros petrofísicos más relevantes de los materiales estudiados. Todos los materiales tiene un grado de compacidad alto, con una velocidad de propagación de ultrasonidos superiores a $4.500 \mathrm{~m} / \mathrm{s}$, a excepción de la Facies A, en donde la velocidad de propagación es baja, con valores medios de $2.265 \mathrm{~m} / \mathrm{s}$ e índices de compacidad de 0,69. Estos the nature of its soiling is necessary. Sampling by test-specimen extraction of the most characteristic building materials found in the Cathedral was carried out and their petrophysical characteristics were determined, following the RILEM (2) guidelines. A spectrocolorimeter (Minolta CM-2002) was used to identify the color of the stone (3). The chromatic scale used was Cielab (4), under the following conditions: standard illuminant $D_{65}$ and observing angle, $10^{\circ}(5)$. The yellowness index (IA) and whiteness index (IB) were carried out according to ASTM (6) .The methodology specifically for limestone (7), was employed.

Thyrty nine ashlars were selected in order to determine the degree of soiling of the stone. The chromatic coordinates of these ashlars were measured. Fifteen ashlars belonging to Facies $C, 7$ to Facies $B$ and 5 to Facies $A$ were selected from the collegiate church. Twelve ashlars from Facies $E$ (biomicrite), were isolated in the main façade, as this variety is the most representative of this part of the construction. Ten chromatic readings were taken from all over the surface of each ashlar. Each reading was the mean of three other taken from exactly the same position in order to obtain a significant figure for the whole. 1,170 chromatic readings of the soiling were taken.

The dirt crust was analyzed using EDAX scanning electron microscopy (SEM). The chemical analysis was done using the ICP-Emision and ICP-MS technique.

\section{PETROPHYSICAL CHARACTERISTICS}

Table 1 contains data about the natural color of these materials. All the materials are characterized by the high luminosity of their hues, with figures ranging from 70 to 80 units. Values for the Facies found on side entrance to the collegiate are slightly lower. The presence of yellow hues in the stone, defined by parameter $+b^{*}$, is higher in Facies $A$ y $F$, the latter having the highest yellow index (IA), with figures close to 17. The whiteness index (IB) is similar for all stone varieties. The highest values corresponds to Facies D.

Table II shows the most significant petrophysical parameters of the materials analyzed. All the materials are highly compact with an ultrasound propagation velocity above $4,500 \mathrm{~m} / \mathrm{s}$, except in Facies $A$, where propagation velocity is low, with average values of $2,265 \mathrm{~m} / \mathrm{s}$ and a compactness index of 0.69. The latter materials show evidence of 
TABLA I (TABLE I)

Parámetros cromáticos de los materiales pétreos originales (Chromatic parameters of original stone materials)

\begin{tabular}{|c|c|c|c|c|c|c|c|}
\hline & & $\mathrm{L}^{*}$ & $a^{*}$ & $\mathrm{~b}^{*}$ & $C^{*}$ & IA & IB \\
\hline \multirow[t]{2}{*}{ FACIES A } & $\begin{array}{l}\text { Media } \\
\text { Mean }\end{array}$ & 79,2 & 0,7 & 10,0 & 10,1 & 17,4 & 17,1 \\
\hline & Std & 1,34 & 0,18 & 0,76 & 0,76 & 1,37 & 3,49 \\
\hline \multirow[t]{2}{*}{ FACIES B } & $\begin{array}{l}\text { Media } \\
\text { Mean }\end{array}$ & 67,5 & 2,2 & 6,2 & 6,6 & 12,7 & 18,5 \\
\hline & Std & 2,05 & 0,55 & 1,74 & 1,83 & 3,98 & 5,85 \\
\hline \multirow[t]{2}{*}{ FACIES C } & $\begin{array}{l}\text { Media } \\
\text { Mean }\end{array}$ & 65,5 & 2,5 & 7,0 & 7,5 & 14,6 & 14,6 \\
\hline & Std & 1,54 & 0,22 & 0,33 & 0,37 & 0,84 & 1,88 \\
\hline \multirow[t]{2}{*}{ FACIES D } & $\begin{array}{l}\text { Media } \\
\text { Mean }\end{array}$ & 79,3 & 1,7 & 7,4 & 7,6 & 13,1 & 26,7 \\
\hline & Std & 1,11 & 0,22 & 0,53 & 0,54 & 0,96 & 2,63 \\
\hline \multirow[t]{2}{*}{ FACIES E } & $\begin{array}{l}\text { Media } \\
\text { Mean }\end{array}$ & 72,3 & 3,2 & 9,0 & 9,6 & 17,2 & 13,9 \\
\hline & Std & 1,21 & 0,43 & 0,90 & 1,00 & 1,84 & 3,72 \\
\hline
\end{tabular}

$\mathrm{L}^{*}=$ Luminosidad. $\mathrm{a}^{*}=$ Tono rojo. $\mathrm{b}^{*}=$ Tono amarillo. $\mathrm{C}^{*}=$ Croma o saturación.

IA = Índice de amarillo. IB = Índice de blancura

$L^{*}=$ Luminosity. $a^{*}=$ Red hue. $b^{*}=$ Yellow hue. $C^{*}=$ Chroma.

$I A=$ Yellow index. $I B=$ Whiteness index).

materiales son los que presentan procesos de degradación superficial importantes. La arenización ha eliminado las formas originales de los sillares labrados con estos materiales, en la portada principal de la colegiata. Son estos materiales los que tiene, además, un mayor grado de saturación al agua, con valores medios del $16,6 \%$.

Uno de los parámetros petrofísicos más importantes para conocer la inocuidad de la limpieza en húmedo, junto a la compacidad, es la cinemática de sorción y desorción o evaporación de agua. Cuanto menor sea la cantidad de agua que penetre en el interior de la piedra, y más rápido sea su secado, mayor será la resistencia de los materiales a sufrir procesos de degradación por disoluciones, hidrataciones, etc., así como los debidos a la degradación mecánica por acción del hielo y sales. Todos los materiales con los que está construida la Catedral tienen un comportamiento hídrico bueno. La cantidad de agua que absorben, en la primera hora, se muestra en la Tabla II. Esta cantidad de agua es baja a considerable surface degradation where the grain disgregation has worn off the original shapes of the carved stone in the main façade of the collegiate. These materials also have a higher degree of water saturation with average figures of $16.6 \%$.

Besides compactness, water-sorption and desorption, or evaporation, cinematics, are one of the most significant petrophysical parameters to determine whether a water-based cleaning method is innocuous. The smaller the amount of water that penetrates the stone, and the quicker its drying process, the less likely it is that the stone may suffer degradation due to dissolutions, hydrations and similar processes or mechanical degradation induced by the action of ice or salts. All the materials employed in the construction of the Cathedral display a good hydric behaviour. Table II shows the amount of water absorbed by the stones during the 
TABLA II (TABLE II)

Características petrofísicas (Petrophysical characteristics)

\begin{tabular}{|c|c|c|c|c|c|}
\hline & \multicolumn{3}{|c|}{$\begin{array}{l}\text { COLEGIATA } \\
\text { (COLLEGIATE) }\end{array}$} & \multicolumn{2}{|c|}{$\begin{array}{l}\text { CATEDRAL } \\
\text { (CATHEDRAL) }\end{array}$} \\
\hline & A & B & C & D & $\mathrm{E}$ \\
\hline $\begin{array}{l}\text { Densidad real }\left(\mathrm{kg} / \mathrm{m}^{3}\right) \\
\text { (Real density) }\end{array}$ & 2.705 & 2.659 & 2.658 & 2.702 & 2.682 \\
\hline $\begin{array}{l}\text { Densidad aparente }\left(\mathrm{kg} / \mathrm{m}^{3}\right) \\
\text { (Bulk density) }\end{array}$ & 1.870 & 2.629 & 2.283 & 2.365 & 2.520 \\
\hline $\begin{array}{l}\text { Porosidad accesible }(\%) \\
\text { (Open porosity) }\end{array}$ & 30,9 & 1,1 & 12,9 & 12,4 & 5,4 \\
\hline $\begin{array}{l}\text { \% Saturación } \\
\text { (Saturation) }\end{array}$ & 16,6 & 0,41 & 5,6 & 5,4 & 2,1 \\
\hline $\begin{array}{l}\text { Índice de Compacidad } \\
\text { (Compactness index) }\end{array}$ & 0,69 & 0,99 & 0,88 & 0,87 & 0,95 \\
\hline $\begin{array}{l}\text { Coeficiente capilar }\left(\mathrm{kg} / \mathrm{m}^{2} \mathrm{~h}^{12}\right) \\
\text { (Capillarity coefficient) }\end{array}$ & 1,28 & 0,06 & 1,26 & 1,09 & 0,16 \\
\hline $\begin{array}{l}\text { Permeabilidad }\left(\mathrm{g} / \mathrm{m}^{2} \mathrm{~h}\right) \\
\text { (Permeability) }\end{array}$ & 44,72 & 7,26 & 20,27 & 3,17 & 1,54 \\
\hline $\begin{array}{l}\text { Coeficiente de permeabilidad } \\
(\text { Permeability coefficient }) \\
\left(\mathrm{g} / \mathrm{m}^{2}, 24 \mathrm{~h} \mathrm{mmHg}\right)\end{array}$ & 5,25 & 1,11 & 3,27 & 0,58 & 0,19 \\
\hline $\begin{array}{l}\text { Velocidad de ultrasonidos }(\mathrm{m} / \mathrm{s}) \\
\text { (Ultrasound velocity) }\end{array}$ & 2.265 & 5.480 & 4.528 & 5.493 & 5.345 \\
\hline
\end{tabular}

excepción de la pelmicrita detrítica que alcanza valores del 13,2\%. La velocidad de secado es alta, para casi todos los materiales, al perder, a las 24 horas, el agua absorbida en una semana. Únicamente las pelmicritas de la Facies $\mathrm{C}$ conservan, en su interior, un 5,3\% de agua, y al cabo de una semana todavía permanece un $2 \%$ (Figura 1).

\section{GRADO DE ENSUCIAMIENTO}

En la colegiata son los paramentos verticales de entrada a la misma los que presentan un ensuciamiento más intenso, producido por el enmugrecimiento de la contaminación. Pero posiblemente, son las fachadas de la Catedral Nueva las que presentan un grado de enmugrecimiento más alto, con importantes contrastes cromáticos por alternar zonas de costras negras y zonas lavadas por la acción del agua de lluvia. Este mayor ennegrecimiento de la fachada principal es debido a que se encuentra orientada en la dirección opuesta a first hour. The amounts registered are small except in the case of the detrital pelmicrite, where it reaches values of $13.2 \%$. The drying velocity is high, therefore almost all materials loose the water absorbed 24 hours after saturation. Only the pelmicrites keep 5.3\% of the water absorbed inside, of which $2 \%$ still remains after a week (Figure 1).

\section{DEGREE OF SOILING}

The highest degree of soiling in the collegiate church is found in the vertical facing at the entrance and is induced by pollution. However, the façades of the Catedral Nueva possibly register the highest degree of soiling, with important chromatic contrasts due to the presence of black encrusted layers alongside sections washed by rainwater. This blackening of the main façade is due to its orientation, opposing the 


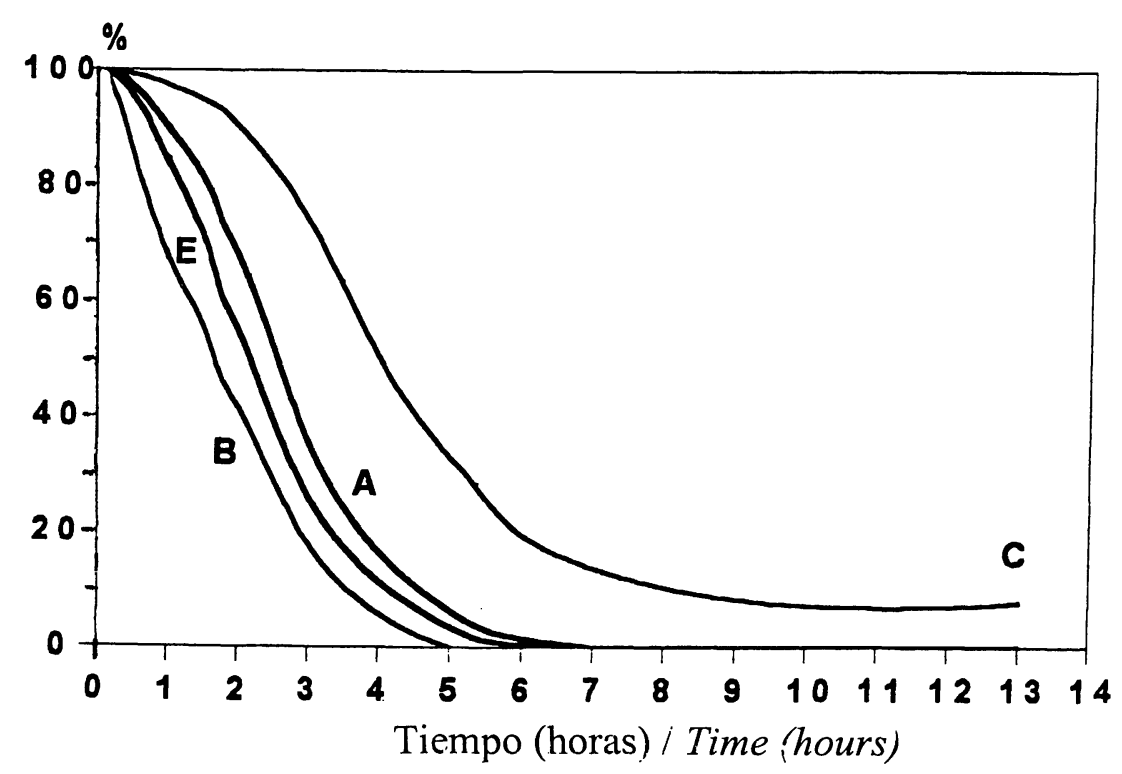

Figura 1.- Pérdida de agua durante el proceso de evaporación. A) Pelmicrita; B) Micrita fosilifera; C) Pelmicrita fosilifera; E) Biomicrita.

Figure 1.- Water loos during the evaporation process. A) Pelmicrite; B) Fossiliferous micrite; C) Fossiliferous pelmicrite; E) Biomicrite.

los vientos dominantes, de donde proceden los contaminantes principales, por lo que es más fácil su adhesión en la superficie de la fachada.

En la Facies C (pelmicritas fosilíferas) el cambio más significativo es la pérdida de luminosidad o claridad de la piedra al pasar de un valor medio de 65,5 a 40,6 (Tabla III). El resto de los parámetros cromáticos presentan también variaciones. Las coordenadas $b^{*}$ tienden a aumentar con el ensuciamiento y, con ello, la croma y el ángulo hue. El índice de amarillo aumenta de 14,6 a 23,6 y, sobre todo, el índice de blancura tiende a disminuir al pasar de 14,6 en la zona interna de la piedra a 0,7 en la superficie más sucia.

La Facies B, también sufre una pérdida de luminosidad de la piedra, por el proceso de enmugrecimiento, al pasar de 67,5 a 34,0 . En esta facies, el ensuciamiento es mayor, tal como lo detecta una mayor pérdida de luminosidad, al igual que la disminución del índice de blanco, que pasa de 18,5 a 0,3. El resto de los parámetros tienden a aumentar, con un cierto enriquecimiento de las tonalidades amarillas.

En la Facies A, existente en la portada, la suciedad se presenta de forma heterogénea por la continua pérdida de material, por el proceso de arenización y desprendimiento de las costras negras, que hace que exista una limpieza natural nada deseable. También, el índice de blancura sufre una disminución muy importante al pasar de 17,1 a 3,6. En estos materiales existe una minoración de los otros parámetros predominant winds that carry the main pollutants, thus encouraging their adhesion to the surface façade.

In Facies $C$ (fossiliferous pelmicrites) the most significant change is the loss of luminosity or clarity of the stone, the mean value dropping from 65.5 to 40.6 (Table III). However, the remaining chromatic parameters are also modified. $b^{*}$ coordinates tend to increase as a result of the soiling and consequently, so do the chroma and the hue angle. The yellow index increases, from 14.6 to 23.6 and, most significantly, the whiteness index tends to decrease, dropping from 14.6 in the inside of the stone to 0.7 in the most soiled surfaces.

Facies $B$ also undergoes a loss in luminosity induced by the soiling process and its values drop from 67.5 to 34.0. In this Facies, the degree of soiling is higher, as becomes apparent by its luminosity loss and by the decrease in whiteness index values, from 18.5 to 0.3 . The remaining parameters tend to increase, with a slight increase in yellow hues.

The presence of soiling in Facies $A$, found in the main façade, is heterogeneous due to the ongoing loss of material due to the grain-disgregation process and the detachment of black layers, which constitute an undesirable natural cleaning process. There is also a decrease in the whiteness index, that falls from 17.1 to 3.6. The remaining parameters for this variety of stone also decrease: the stone looses yellow hues and is less 
TABLA III (TABLE III)

Parámetros cromáticos en los sillares del conjunto catedralicio (Chromatic parameters od the cathedral ashlaring)

\begin{tabular}{|c|c|c|c|c|c|c|c|}
\hline & & $\mathrm{L}^{*}$ & $a^{*}$ & $b^{*}$ & $C^{*}$ & IA & IB \\
\hline \multirow[t]{2}{*}{ FACIES A } & $\begin{array}{l}\text { Media } \\
\text { Mean }\end{array}$ & 42,6 & 1,3 & 6,5 & 6,6 & 18,4 & 3,6 \\
\hline & Std & 5,92 & 0,67 & 1,56 & 1,66 & 4,11 & 2,24 \\
\hline \multirow[t]{2}{*}{ FACIES B } & $\begin{array}{l}\text { Media } \\
\text { Mean }\end{array}$ & 34,0 & 1,9 & 7,4 & 7,6 & 23,8 & 0,3 \\
\hline & Std & 2,71 & 0,52 & 1,52 & 1,59 & 3,9 & 1,36 \\
\hline \multirow[t]{2}{*}{ FACIES C } & $\begin{array}{l}\text { Media } \\
\text { Mean }\end{array}$ & 40,6 & 1,9 & 8,2 & 8,4 & 23,6 & 0,7 \\
\hline & Std & 2,95 & 0,47 & 1,34 & 1,4 & 3,46 & 1,86 \\
\hline \multirow[t]{2}{*}{ FACIES E } & $\begin{array}{l}\text { Media } \\
\text { Mean }\end{array}$ & 36,3 & 1,7 & 6,0 & 6,3 & 18,8 & 2,1 \\
\hline & Std & 5,85 & 0,62 & 1,93 & 2,0 & 4,55 & 1,53 \\
\hline
\end{tabular}

$\mathrm{L}^{*}=$ Luminosidad. $\mathrm{a}^{*}=$ Tono rojo. $\mathrm{b}^{*}=$ Tono amarillo. $\mathrm{C}^{*}=$ Croma o saturación

IA = Índice de amarillo. IB = Índice de blancura

$L^{*}$ Luminosity. $a^{*}=$ Red hue. $b^{*}=$ Yellow hue. $C^{*}=$ Chroma.

$I A=$ Yellow index. $I B=$ Whiteness index $)$

cromáticos, disminuyendo ligeramente su tonalidad amarilla natural de la piedra y teniendo un grado de saturación menor, adquiriendo un color más apagado. En la fachada principal de la Catedral el grado de ensuciamiento es alto, tal como se puede apreciar por las diferencias cromáticas en las zonas sucias y las zonas lavadas por la lluvia. Las diferencias de luminosidad media de las piedras son de 40,4 unidades. El resto de parámetros cromáticos presentan diferencias entre las zonas sucias y las limpias. La Figura 2 muestra las variaciones cromáticas de las distintas facies petrológicas existentes en el conjunto catedralicio con respecto a su color original. Se puede indicar que existe una perdida de la luminosidad para todos los materiales. Son los localizados en la fachada principal de la Catedral y en la portada de la colegiata los que tienen una menor luminosidad y una mayor variación de la croma o saturación del color. saturated, henceforth, the color is less vibrant. In the Cathedral main façade, the degree of soiling is high, as is apparent by the chromatic differences between soiled sections and those washed by rainwater. There is a variation of 40.4 units in the average luminosity of the stone. The remaining chromatic parameters also reflect differences between soiled and washed sections. Figure 2 reflects the chromatic variations in the different petrological Facies found in the cathedral constructions in relation to their original color. It can be noted that all materials undergo a loss in luminosity. Stones located in the Cathedral façade and in that of the collegiate have the lowest luminosity levels, and the most pronounced chroma variation or color saturation. 


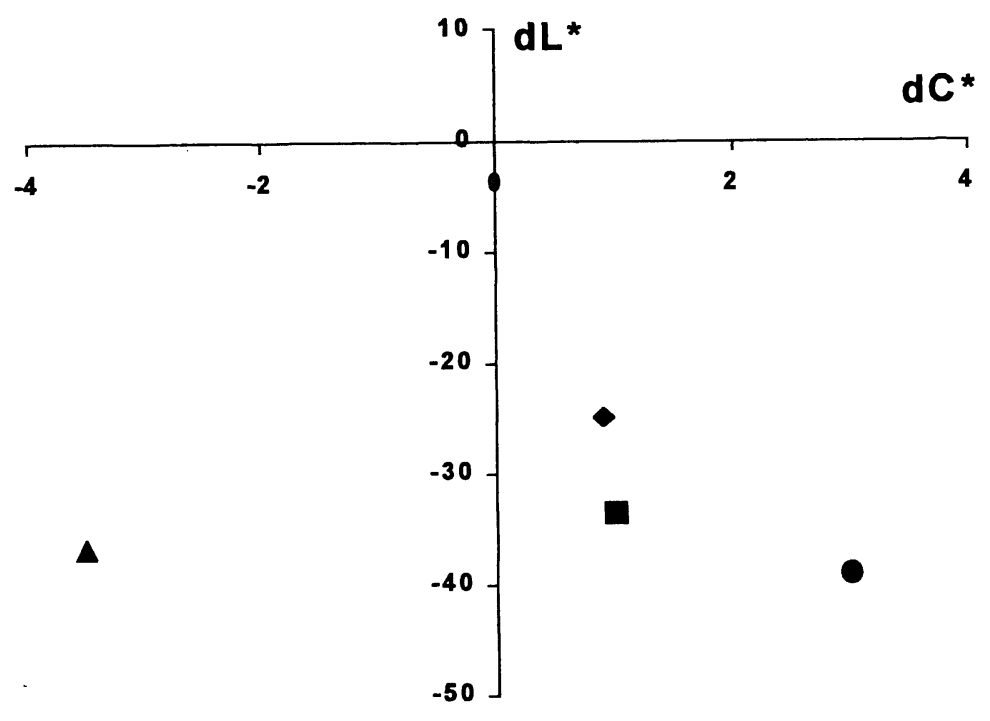

Figura 2.- $\mathrm{dL}^{*}$ y dC* de los paramentos con respecto al color original de las piedras. Triángulo: pelmicritas (Facies A). Cuadrado: micrita fosilifera (Facies B). Rombo: pelmicritas fosiliferas (Facies C). Círculo: Biomicritas (facies E).

Figure 2.- $d L^{*}$ and $d L^{*}$ of façade in relation to the original color of the stones. Triangle. pelmicrites (Facies A). Square: fossiliferous micrite (Facies B). Rhomb: fossiliferous pelmicrites (Facies C). Circle: biomicrites (Facies E).

\section{NATURALEZA DEL ENSUCIAMIENTO}

El Monumento presenta un enmugrecimiento general de sus paramentos y costras negras en zonas localizadas. En estas costras negras, al microscopio electrónico, se observan perfectos euhedros de dolomita, junto con cristales lenticulares de yeso, e incluso esferas con puntos crateriformes (Figura 3), producto de la contaminación ambiental, resultado de la combustión de los hidrocarburos. En el análisis espectral, se pone de manifiesto dicha composición junto con algún resto de silicoaluminato potásico (feldespatos potásicos), con presencia de hierro.

El análisis químico de las costras de la Catedral se muestran en la Tabla IV. Se aprecia cómo en las zonas internas de las costras su composición química es muy similar a la del soporte. En la parte externa de la costra, disminuye el porcentaje de calcio, por procesos de disolución y, el resto, se presenta en forma de yeso, que es detectado por el aumento de estroncio.

Respecto a los elementos traza existe un incremento importante del estroncio y, en menor grado, del rubidio, que es característico del proceso de sulfatación. El resto de elementos son catalizadores del proceso de contaminación atmosférica, favoreciendo que el dióxido de azufre se transforme a

\section{NATURE OF SOILING-CRUSTS}

All the cathedral facing is soiled and some overlaid with black crusts in specific areas. Under inspection with electron microscope it can be observed that these black crusts contain perfect dolomite euhedrum and lenticular gypsum crystals and even spheres with crateriform point (Figure 3) induced by environmental pollution caused by hydrocarbon combustion. Spectral analysis reveals the calcium-magnesium composition and some traces of potasium silicoaluminate (feldspar $K)$ with presence of iron.

The results of the chemical analysis of the black crusts on the Cathedral stone are shown in Table IV. It can be observed that the chemical composition of the internal sections of the crust is very similar to that of the stone. The external sections of the crust contain lower percentages of calcium, as a result of dissolution processes, and the rest takes the form of gypsum, that is identified by the increase in strontium.

With regards to trace elements, a significant increase in the presence of rubidium and, especially, strontium -characteristic of the sulfation processwas detected. The remaining elements are catalysts of environmental pollution contributing to the transformation of sulfur dioxide into trioxide and the 


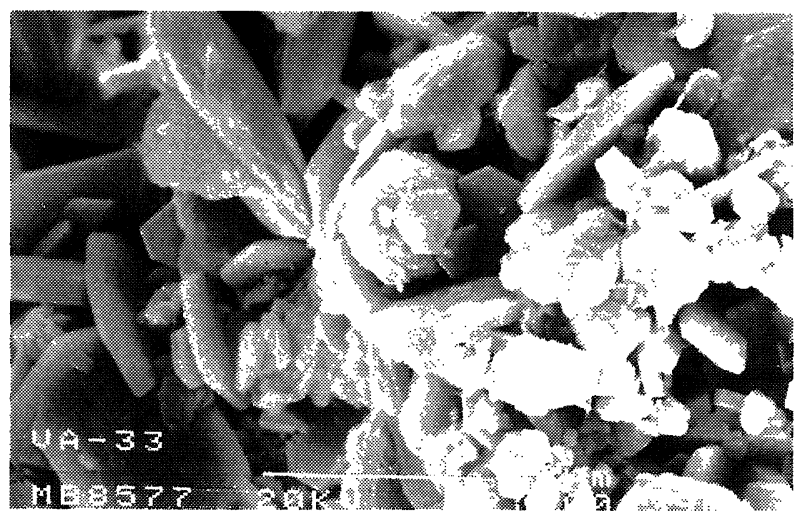

Figura 3.- Detalle de la costra de suciedad de la fachada principal. Detail of a dirt crust in te main façade.

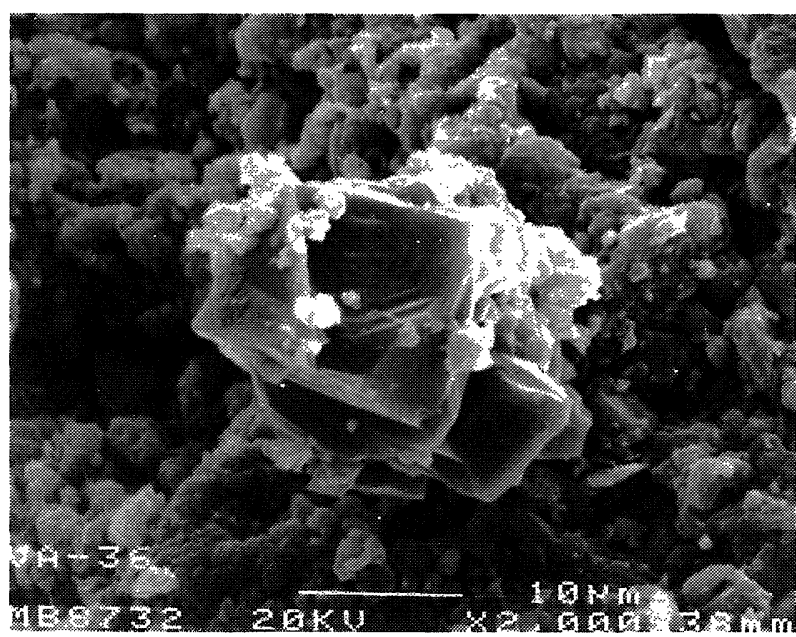

Figura 4.- Aspecto de la costra negra calcítica de la Torre Aspect of the calcitic black crust in the Tower.

TABLA IV (TABLE IV)

Análisis químico del soporte y las costras (Chemical analysis of the substrate and the crusts)

\begin{tabular}{||c|c|c|c||}
\hline \multirow{2}{*}{$\%$} & \multirow{2}{*}{ Soporte (Support) } & \multicolumn{2}{|c|}{ Costra (Crusts) } \\
\cline { 3 - 4 } & & Interior & Exterior \\
\hline $\mathrm{SiO}_{2}$ & 1,27 & 2,16 & 12,13 \\
\hline $\mathrm{Al}_{2} \mathrm{O}_{3}$ & 0,49 & 0,43 & 4,61 \\
\hline $\mathrm{Fe}_{2} \mathrm{O}_{3}$ & 0,04 & 0,02 & 1,65 \\
\hline $\mathrm{MnO}$ & $\mathrm{tz}$ & $\mathrm{tz}$ & 0,03 \\
\hline $\mathrm{MgO}$ & 0,45 & 0,69 & 2,01 \\
\hline $\mathrm{CaO}$ & 53,54 & 53,19 & 30,46 \\
\hline $\mathrm{Na}_{2} \mathrm{O}$ & $\mathrm{tz}$ & 0,07 & 1,37 \\
\hline $\mathrm{K}_{2} \mathrm{O}$ & 0,05 & 0,1 & 1,37 \\
\hline $\mathrm{TiO} \mathrm{O}_{2}$ & 0,02 & 0,03 & 0,16 \\
\hline $\mathrm{P} \mathrm{O}_{5}$ & 0,08 & 0,09 & 0,22 \\
\hline $\mathrm{ppm}$ & & & 23,9 \\
\hline $\mathrm{Ni}$ & 12,2 & 17,6 & 77,3 \\
\hline $\mathrm{Pb}$ & 0,25 & 0,73 & 39,2 \\
\hline $\mathrm{Rb}$ & 3,20 & 4,93 & 2.050 \\
\hline $\mathrm{Sr}$ & 382 & 403 & 37,7 \\
\hline $\mathrm{V}$ & -- & 2,78 & 55,1 \\
\hline $\mathrm{Zn}$ & & 3,47 & \\
\hline
\end{tabular}


trióxido, y éste a ácido sulfúrico. De forma espectacular aumenta la proporción del plomo por la gasolina y los catalizadores, especialmente el pentóxido de vanadio, reconcentrándose el rubidio y el estroncio, acompañantes del calcio en los yesos de las costras.

Junto a estas costras yesíferas, existen otras, de naturaleza calcítica (Figura 4), muy difíciles de separar del soporte. En estos casos, se trata de un proceso de disolución de la caliza del soporte y, el bicarbonato cálcico, formado en la disolución, al impregnar la roca de aguas acidificadas por el dióxido de carbono, sale a la superficie y donde, al desecarse, forma una costra de carbonato cálcico, que se empapa de humos contaminantes, y origina las costras negras carbonáticas.

\section{ENSAYOS DE LIMPIEZA IN SITU}

De los distintos métodos de limpieza que existen para su aplicación sobre materiales pétreos (8), se ha seleccionado la limpieza en húmedo, en un principio, como el más adecuado para el conjunto catedralicio. Este método puede ser el genérico para todos los materiales del monumento, dado que las características petrofísicas y, sobre todo, del comportamiento hídrico de sus materiales, nos asegura que la piedra no va a sufrir deterioros significativos. Únicamente la Facies A, que tiene un grado de compacidad bajo y una porosidad accesible al agua alta, es la que puede sufrir un deterioro mayor durante la limpieza en húmedo, por lo que es necesario controlar, en todo momento, las condiciones de actuación.

La limpieza en seco, por medio de chorro de arena, al ser un sistema más agresivo, que llega a eliminar la pátina original del monumento, es desaconsejable y, únicamente en zonas concretas se podría aplicar por medio de microproyección de partículas, controlando, en todo momento, la presión de actuación (micropulido), incluso sería mejor realizar este microchorreado de las partículas proyectadas en húmedo (técnica Torbo). La utilización de técnicas de láser aunque es muy efectiva para este tipo de materiales, no es viable, debido a la gran superficie a limpiar.

Para determinar las condiciones de presión y temperatura del agua más adecuadas para la limpieza de los diferentes materiales se procedió, en cada una de las zonas piloto y para cada uno de los sillares, a una limpieza selectiva. Los resultados obtenidos indican que la limpieza no era efectiva a una temperatura inferior a $90^{\circ} \mathrm{C}$ y una presión inferior a 120 bares. Además, atendiendo a la naturaleza de la suciedad de los paramentos, la eliminación total de las costras únicamente se podría realizar con productos de limpieza de tipo alcalino (hidróxido sódico con metasilicato sódico, EDTA en una solución de hipoclorito sódico y latter, in turn, into sulfhuric acid. The ratio of lead increases dramatically as an effect of petrol and as do the catalysts, vanadium pentoxide in particular, with a higher concentration of rubidium and strontium, that are found alongside calcium in the gypsum that forms the crusts.

As well as these gypsum-based crusts, there are other of calcitic nature (Figure 4) that are very difficult to remove from the stone. These crusts appear as a consequence of dissolution processes in the limestone. Calcium bicarbonate, side product of these processes by impregnating the stone with acidified water by the carbon dioxide. As it dries, a calcium carbonate crust is formed, and this crust absorbs the pollution fumes thus originating the black carbon-based crusts.

\section{IN SITU CLEANING TEST}

Of all the different cleaning methods that can be applied to stone (8), wet cleaning has been selected a priori as the most effective method for the cathedral. This method can be applied to the entirety of the materials used to build the monument, since their petrophysical characteristics and, most importantly, their hydric behavior ensure that the stone is not going to suffer significant deterioration. Only Facies $A$, a low density material with high porosity, accessible for water, can suffer a higher degree of deterioration throughout the cleaning, in view of which, cleaning conditions for this variety must be monitored at all times.

Dry cleaning methods such as sandblasting are more aggressive and can wear the natural patina of the monument off; its use is therefore not advisable and will only be necessary in specific areas, where microprojection of particles could be applied, controlling the pressure at all times (micropolishing). Nonetheless microblasting of particles mixed with water (Torbo technique) might be more advisable. The use of laser is very effective for these materials but it is not feasible on account of the size of the surface to be cleaned.

In order to determine the optimum water pressure and temperature to clean the different materials, each of the sample areas and ashlars was cleaned using selective techniques. The results obtained indicate that cleaning was not effective at a temperature below $90^{\circ} \mathrm{C}$ or a pressure below 120 bars. Also, in view of the nature of the soiling in the stone, the complete removal of the crusts could only be accomplished with the use of alkaline cleaning products (sodium hydroxide with sodium metasilicate, EDTA, in a sodium hypoclorite and gel solution) that had already been proved effective in 
gel), que dieron buenos resultados en materiales similares (9). El tiempo de aplicación del hidróxido sódico fue de 20 minutos, siendo, posteriormente, eliminado con abundante agua.

La aplicación de productos ácidos no es aconsejable debido a la disolución de la superficie de la piedra calcárea y a la consiguiente formación de sales.

Después de la limpieza, y pasados 15 días, se procedió a determinar las coordenadas cromáticas, realizando 30 medidas en cada uno de los sillares, siguiendo la misma metodología que antes de los tratamientos de limpieza.

En la colegiata, debido a que presenta diferentes tipos de materiales con un grado de compacidad y porosidad diferentes es necesario controlar la cantidad de agua y, sobre todo, la presión de actuación durante la limpieza.

Los resultados sobre los sillares de Facies $\mathrm{C}$, tratados a alta presión (120 bares) y alta temperatura $\left(90^{\circ} \mathrm{C}\right)$, muestran escasa mejoría, con un incremento de la luminosidad de 4,8 unidades, permaneciendo el resto de los parámetros casi iguales. Los resultados obtenidos son mucho mejores cuando se aplica el compuesto basado en hidróxido sódico. En este caso, el aumento de la luminosidad es de 20 unidades, apreciándose también un aumento del resto de los parámetros.

En el paramento construido con micrita fosilífera (Facies B), los resultados obtenidos son similares. Los mejores resultados se obtienen con la aplicación previa de hidróxido de sodio. El incremento de luminosidad es mayor que el obtenido en los materiales del paramento de la izquierda, pertenecientes a la Facies $\mathrm{C}$, al pasar de 35,3 de luminosidad a 67,0 después de la limpieza, con un incremento medio de 31,7 unidades. También hay que destacar que la limpieza con esta técnica es más homogénea que con agua sola, ya que la desviación estándar es en la primera de 13,6 unidades y con el producto de limpieza de 5,6. A pesar de todo ello, los resultados, comparados con respecto al color natural de la piedra, no se alcanzan, al igual que ocurre con el resto de los materiales tratados (Figura 5).

Los materiales de la portada son más delicados a la hora de su limpieza, teniendo en cuenta su grado de arenización, falta de consistencia y parámetros petrofisicos, lo que hace que su limpieza tenga que realizarse de una forma individualizada para cada sillar y contrastada en cada momento. El método utilizado, en un principio, es el mismo que en el resto del monumento, aunque con un control más preciso de la presión de agua y el tiempo de aplicación de productos. Los mejores resultados se alcanzan con la aplicación previa del similar materials (9). The application time of sodium hydroxide was 20 minutes, and it was later rinsed with abundant water.

The use of acidic products is not advisable owing to the dissolution of the surface of calcareous stones and the salt formation that takes place as a result.

Once the cleaning process came to an end and after a period of 15 days, the chromatic coordinates were determined with 30 readings taken from each of the ashlars, following the same methodology as was used before the cleaning.

Due to the combination of different materials in the collegiate church, with varying degrees of compactness and porosity, it is necessary to control the amount of water used in the cleaning process and specially the pressure at which the water acts.

The results for ashlars of Facies $C$, cleaned at high pressure (120 bars) and high temperature $\left(90^{\circ} \mathrm{C}\right)$, reflect a limited improvement with an increase in luminosity of 4.8 units, while the remaining parameters scarcely change. Performance is significantly improved by applying a sodium hydroxide based product, after which an increase in luminosity of 20 units, and an increase in other parameters was observed.

For the fossiliferous micrite (Facies B) facing, the results obtained are similar. Best results are obtained when sodium hydroxide is applied prior to the cleaning process. The increase in luminosity is higher than that obtained for the ashlaring on the left side, that belongs to Facies $C$, with values rising from 35.3 to 67.0 after cleaning, an increase of 31.7 units. It must also be noted that cleaning with this technique produces more homogeneous results than solely with water, since the standard deviation in the latter case is of 13.6 units, whereas with the treatment using a cleaning product it was of 5.6 units. However, a comparative analysis of the results obtained and the natural color of the stone demonstrates that these do not match completely, as is the case with the other materials treated (Figure 5).

The materials found in the façade are more sensitive to the potential harming effects of cleaning due to their degree of grain-desintegration, their lack of consistency and their petrophysical parameters. In view of this, cleaning has to be done one ashlar at a time and the process constantly supervised. The method used at the outset is the same as that applied to the other parts of the monument but deploying strict control of water pressure and product application time. Best results are obtained when a sodium hydroxide based product is 


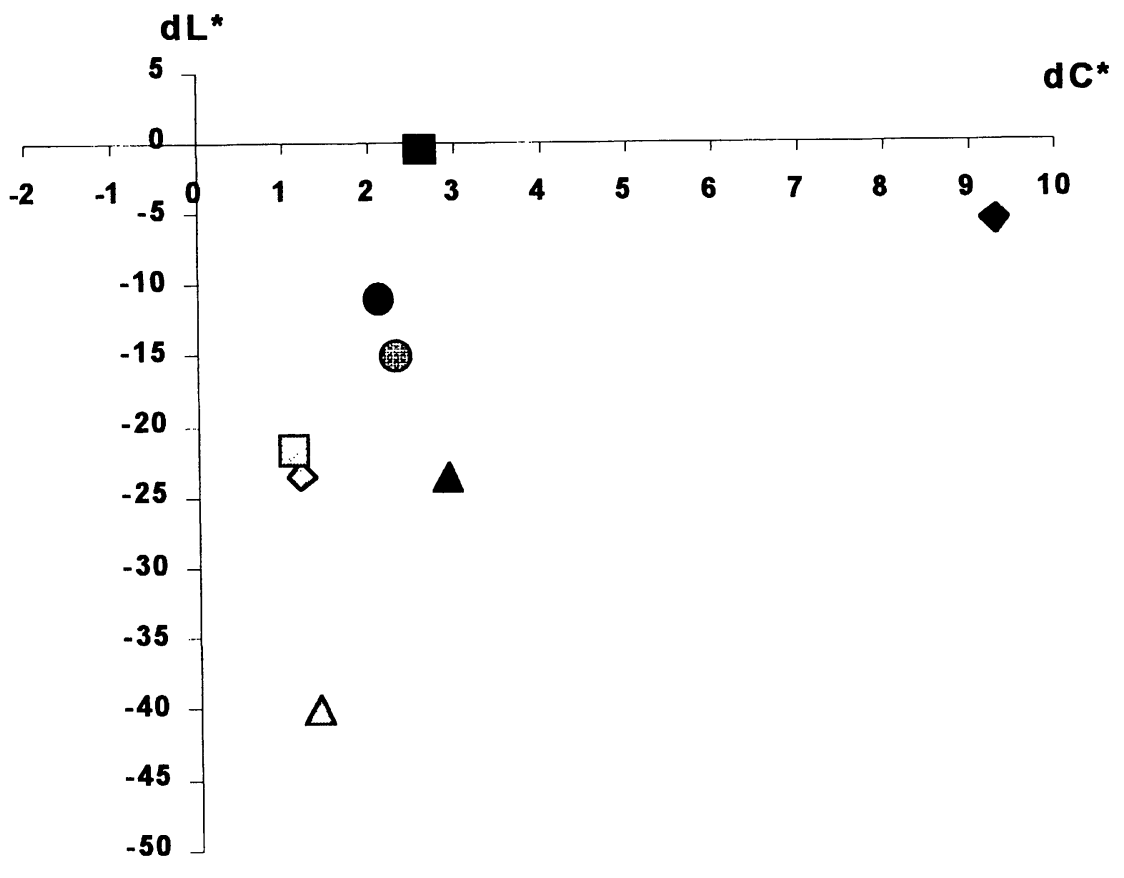

Figura 5.- Eficacia de los tratamientos en los distintos materiales. Triángulo: pelmicritas (facies A). Cuadrado: micrita fosilífera (Facies B). Rombo: pelmicritas fosiliferas (Facies C). Círculo: biomicritas (facies E). En blanco: limpieza con agua sólo $\left(90^{\circ} \mathrm{C}\right.$ y 120 bares). Negro: producto alcalino.

Figure 5.- Effectiveness of cleaning treatments for different materials. Triangle: pelmicrites (Facies A). Square: fossiliferous micrite (Facies B). Rhomb: fossiliferous pelmicrites (Facies C). Circle: biomicrites (Facies E). White: only water $\left(90{ }^{\circ} \mathrm{C}\right.$ y 120 bares). Black: product alkaline.

producto a base de hidróxido de sodio durante 5 minutos y chorro de agua a $120^{\circ} \mathrm{C}$, con una presión no superior a 50 bares.

Para la fachada principal de la Catedral, los mejores resultados se obtienen cuando se aplica sobre los sillares con mayor encostramiento el producto alcalino $\mathrm{y}$, posteriormente, se limpian con agua caliente a $90^{\circ} \mathrm{C}$ y una presión de 120 bares. Los resultados obtenidos, aunque son los que más se acercan al color original de la piedra, no los alcanzan, existiendo unas diferencias de luminosidad entre ambos de 17,8 unidades. Las diferencias en las coordenadas $a^{*}$ y $b^{*}$ son de 0,2 y 2,1 unidades, respectivamente.

En estos tratamientos el índice de blancura se mantiene similar al de la piedra sin limpiar, mientras que el índice de amarillo muestra unos valores más altos. Este íncremento del amarillo es debido a la presencia de la pátina de envejecimiento natural de la piedra o una pátina artificial, que se mantiene después de la limpieza, aunque no se puede descartar el incremento de amarillo por acción del hidróxido de sodio utilizado en la limpieza.

En la Figura 5 se muestran las variaciones de luminosidad y croma de los diferentes materiales después de la limpieza. Se aprecia cómo la aplicación applied for 5 minutes prior to cleaning with a water jet at a temperature of $120^{\circ} \mathrm{C}$ and pressure below 50 bars

For the main façade, best results are obtained when is applied alkaline products, on the ashlars with more encrusted dirt and they are later cleaned with water at $90{ }^{\circ} \mathrm{C}$ and a pressure of 120 bars. Although the results obtained on this stone are the ones that resemble most the original color of the stone, they still do not match it, with differences in luminosity of 17.8 units and in coordinates $a^{*}$ and $b^{*}$ of 0.2 units and 2.1 units respectively.

After these treatments the whiteness index values scarcely change in relation to those for the uncleaned stone, while the yellow Index reaches higher values. This increase in the presence of yellow has two possible origins: the natural ageing patina of the stone or an artificial patina, which are preserved during cleaning, nonetheless, the possibility that the increase in yellow hues may be a side effect of the use of sodium hydroxide cannot be overlooked.

Figure 5 shows the variations in luminosity and chroma that have taken place in the different materials after cleaning. It can be observed that cleaning using 
únicamente de agua, aunque sea a alta temperatura y presión, no alcanza el cromatismo de la piedra original. Únicamente con la aplicación de productos de limpieza se consiguen valores más altos de luminosidad, pero se produce un aumento de la croma, debido a un aumento del parámetro $b^{*}$, correspondiente al amarillo. Este incremento de amarillo, aunque es debido a que la limpieza puede conservar la pátina de envejecimiento natural, es acentuado por la aplicación del complejo de hidróxido sódico.

\section{CONCLUSIONES}

Los resultados nos indican que el grado de limpieza utilizando solamente agua a temperatura ambiente es insuficiente para eliminar satisfactoriamente la suciedad y encostramientos.

Los mejores resultados se obtienen con una presión de agua de 120 bares y una temperatura de $90^{\circ} \mathrm{C}$.

Las pelmicritas arenosas no pueden ser limpiadas a estas presiones, siendo las condiciones de actuación de 50 bares y $120^{\circ} \mathrm{C}$.

Para eliminar las costras negras es necesario la aplicación del complejo de hidróxido de sodio.

Este tratamiento, aunque aumenta la luminosidad de la piedra, produce un aumento de la croma. Esto es debido al incremento del parámetro b* (amarillo), dando un aspecto más envejecido a la superficie de la piedra.

\section{AGRADECIMIENTOS}

A la Junta de Castilla y León, por la financiación del presente estudio y su autorización para su publicación. Al Cabildo de la Catedral por las facilidades dadas para su ejecución, así como a Elesio Gatón Gómez (arquitecto) por la ayuda prestada. A Miguel Juanco por su ayuda en los trabajos de laboratorio. La empresa Proliser realizó los ensayos in situ de limpieza exclusively water, even at high temperature and pressure, does not afford the chromatism of the original stone. Only with the application of cleaning products higher levels of luminosity are obtained. However, an increase in chroma is also registered, due to an increase in values for parameter $b^{*}$, identified with yellow. Although this increase in the presence of yellow is a direct result of the preservation of the natural ageing patina throughout the cleaning, it is heightened by the use of sodium hydroxide based products.

\section{CONCLUSIONS}

The results indicate that cleaning using solely water at room temperature is not enough to successfully remove dirt and encrusted layers.

Best results are obtained with a water pressure of 120 bars and at a temperature of $90^{\circ} \mathrm{C}$.

Detritic pelmicrites cannot be cleaned at this pressure. The optimum cleaning conditions for this variety are: a pressure of 50 bars and a temperature of $120^{\circ} \mathrm{C}$.

In order to remove black crusts it is necessary to apply a sodium hydroxide complex.

Although this treatment heightens stone luminosity, it also induces a chroma increase. This is due to the increase in parameter $b^{*}$ (yellow), that gives the surface of the stone a more aged appearance.

\section{ACKNOWLEDGMENTS}

We acknowledgments the Junta Castilla and León the financial support of this study as well as permission for this publication. Thanks are given to the Cabildo of the Valladolid Cathedral by the facilities for the works. Elesio Gatón Gómez (architect) helped largely to the work. Miguel Juanco offered laboratory support. The company Proliser carried out in situ cleaning test.

\section{BIBLIOGRAFÍA}

(1) F. Mingarro, M.C. López de Azcona, R. Fort. Estudio de la degradación de los materiales de construcción en la Catedral de Valladolid. p. 87.Informe Junta Castilla y León, 1997.

(2) RILEM, Essais recommandés pour mesurer l'alteration des pierres et évaluer l'efficacité des méthodes de traitement. Matériaux et Construccions, 13,75: 175-253, 1980.

(3) U. Zezza, V. Massa, G. Bortolaso. Non.Destructive on-site spectrophotometric colour testing for building stones. Proceedings of the $3^{\text {rd }}$ International Conferenze on Non-Destructive Testing, Microanalytical Methods and Environmental Evaluation for Study and Conservation of Works old Art, Viterbo, vol. 1 (1992), pp. 539-553.

(4) CIELAB, in Publication CIE n 15.2, Colorimetry, 2nd Edition, Central Bureau of the CIE, Vienna, 1986.

(5) R.W.G. Hunt, Measuring Colour. 2nd Edition, Ellis Horwood Limited, England, 1991. 
(6) ASTM E 313-73, Método Test Estándar para índices de blancura y amarillo de materiales casi blancos y opacos. (reapproved 1979). (7) J. Rodríguez Blanco, R. Fort, Modificaciones cromáticas ante diferentes tratamientos de conservación del Claustro de Santa María La Real de Nieva(Segovia, España). In: Rehabilitación del Patrimonio Arquitectónico y Edificación(Ed. E.M.Sebastian, I.Valverde, Zezza, U.) (1996), 488-493.

(8) J.Ashurst, N. Ashurst. Practical building conservation. Vol. 1- Stone masonry. Gower Technical Press, Great Britain, 1990.

(9) R. Fort, F. Mingarro, M.C. López de Azcona, J. Rodríguez Blanco: Chromatic parameters as performance indicators for stone cleaning techniques, Color research and application (2000).

\section{publicaciones del IETCC/CSIC}

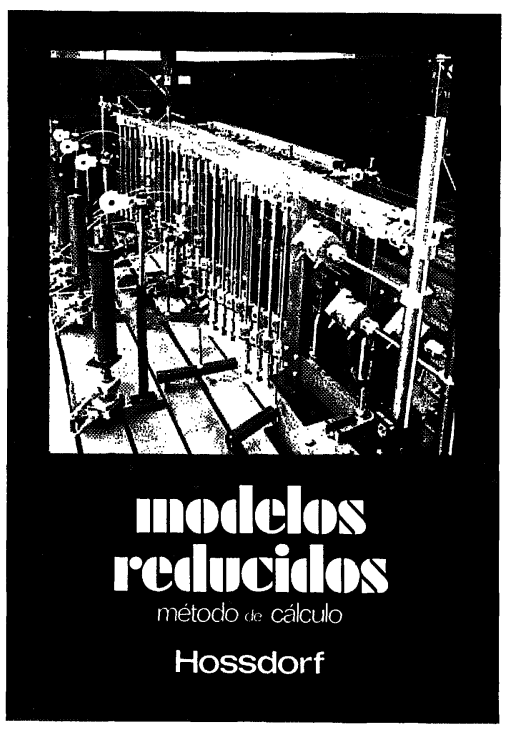

Modelos reducidos. Método de cálculo

H. Hossdorf, Ingeniero Civil

La técnica de los ensayos en modelos reducidos de estructuras sufre hoy dia una decisiva metamorfosis. Hasta hace poco era un medio más bien de artesania, que no siempre era tomado en serio por los académicos teorizantes para comprender el comporta-
miento resistente de las estructuras complejas $y$ al que se acudió las más de las veces, como a un último remedio debido a sus indiscutibles insuficiencias. Sin embargo, en poco tiempo y gracias a su conexión con los ordenadores digitales, se ha transformado en un instrumento científicamente valioso, que no puede quedar a un lado en la práctica diaria del Ingeniero Proyectista.

Un volumen encuadernado en cartoné plastificado con lomo de tela, de $17 \times 24 \mathrm{~cm}$, compuesto de 250 páginas, 158 figuras y fotografias.

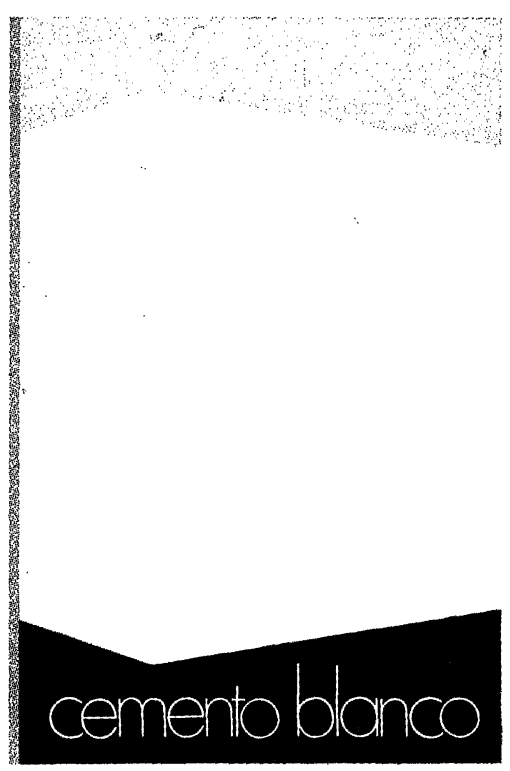

\section{Cemento blanco}

Julián Rezola

Ingeniero Quimico Dipl. I. Q. S.

Sabido es que existe una extensa y documentada bibliografia sobre el cemento gris: en cambio, no puede decirse lo mismo acerca del cemento portland blanco, va que los escritos existentes se refieren tan de aquél.

El autor nos ofrece sus profundos conocimientos y su larga experiencia tanto en laboratorio como en fabricación.

La parte descriptiva del libro se complementa con gráficos, diagramas y fotografias de gran utilidad, destinados a conseguir la aplicación apropiada de

Un volumen encuadernado en cartoné policerado, de $17,4 \times 24,3 \mathrm{~cm}$, compuesto de 395 páginas, numerosas figuras, tablas y ábacos.

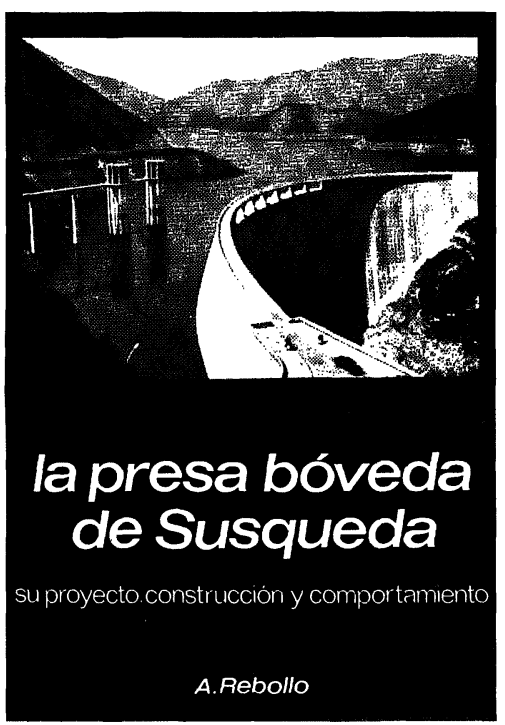

La presa bóveda de Susqueda

A. Rebollo,

Dr. Ingeniero de Caminos

El esfuerzo del constructor de presas se sitúa, por su pretensión de perennidad, a contracorriente de las tendencias de la civilizacion actual, caracterizada por lo fungible. Pueden evocarse las 10.000 grandes. presas en funcionamiento o en construcción que están envejeciendo y reclaman los cuidados gerontológicos para mantener y perfeccionar su servicio y garantizar su inalienable pretensión de perennidad. En la medida en que todas nuevas obras, grandes o pequeñas, son portadoras de riesgos ecologicos $y$, a veces, catastroficos, que aumentan con el envejecimiento, la gerontologia de las presas es todo un emplazo. La accion adelantada a Anuro Rebolo en este terreno marca un camino a devoción patern los que aman su propia obra con

Un volumen encuadernado en cartoné plastificado con lomo de tela, de $18 \times 24,5 \mathrm{~cm}$, compuesto de 408 páginas, 330 figuras y fotografias y 39 tablas. 